\title{
Fish beta diversity responses to environmental heterogeneity and flood pulses are different according to reproductive guild
}

\author{
Ángela Gutiérrez C., Jean Carlo Gonçalves Ortega and Angelo Antonio Agostinho
}

In floodplain communities, beta diversity is influenced by different factors; however, environmental heterogeneity and floods are believed to be particularly influential. The influence of environmental heterogeneity and floods on beta diversity may vary among guilds that present different ecological traits. This study evaluated the correlation between the environmental heterogeneity and flood periods and the beta diversity of trophic and reproductive guilds of fish assemblages. Sampling was conducted quarterly between 2000 and 2012 in the upper Paraná River floodplain. The environmental heterogeneity and period (i.e., dry or flood) were associated with the beta diversity of each guild based on the results of generalized least squares linear models. Only guilds with parental care were influenced by the interaction between environmental heterogeneity and period. The beta diversity of the other guilds presented no relationship between environmental heterogeneity and period. It is likely that species with parental care presented less dispersal capacity, which increased the dissimilarity among assemblages. The higher dispersion rates of the other guilds may be responsible for the lack of relationship between the beta diversity and the environmental heterogeneity and period. In sum, these results suggest that reproductive guilds influence how environmental heterogeneity and floods affect beta diversity variation.

Keywords: Dissimilarity, Fish assemblages, Flood pulse, Reproductive guilds, Trophic guilds.

A diversidade beta é influenciada por diferentes fatores em comunidades de planícies de inundação; contudo, acredita-se que a heterogeneidade ambiental e inundações sejam particularmente influentes. A influência da heterogeneidade ambiental e inundações na diversidade beta podem variar entre guildas que apresentam diferentes características ecológicas. Este estudo avaliou a correlação entre heterogeneidade ambiental, os períodos de inundação e a diversidade beta de guildas tróficas e reprodutivas de peixes. A amostragem foi realizada trimestralmente entre 2000 e 2012 na planície de inundação do Alto rio Paraná. Heterogeneidade ambiental e o período (i.e., seca ou cheia) foram associados à diversidade beta de cada guilda por modelos lineares de quadrados mínimos generalizados. Somente guildas com cuidados parentais foram influenciadas pela interação entre heterogeneidade ambiental e período. A diversidade beta das outras guildas não apresentou relação com heterogeneidade ambiental e período. É provável que espécies com cuidados parentais apresentem menor capacidade de dispersão, o que aumenta a diferença entre as assembleias. As maiores taxas de dispersão de outras guildas podem ser responsáveis pela ausência de relação entre a diversidade beta e heterogeneidade ambiental e o período. Em suma, os resultados sugerem que as guildas reprodutivas influenciam a forma como a heterogeneidade ambiental e as inundações afetam a variação da diversidade beta.

Palavras-chave: Assembleias de peixes, Dissimilaridade, Guildas reprodutivas, Guildas tróficas, Pulso de inundação.

\section{Introduction}

The search for correlates of variation in community composition (beta diversity; Anderson et al., 2011) is a central theme in community ecology (Chase, 2010; Heino et al., 2015b; Zorzal-Almeida et al., 2017). The interactions between environmental factors at regional geographic scales (Heino, 2001; Leprieur et al., 2009; Al-Shami et al., 2013; Heino et al., 2015b;), productivity (Chase, 2010; Bini et al., 2014) and environmental heterogeneity present subs- tantial influences on beta diversity (Bini et al., 2014; Heino et al., 2015b; Zorzal-Almeida et al., 2017). Specifically, environmental heterogeneity is expected to have a positive relationship with beta diversity. The similarities in species composition and environmental conditions and resources tend to decrease as the geographical distance between communities increases (Leprieur et al., 2009; Anderson et al., 2011; Nekola, McGill, 2014; Heino et al., 2015b; ). This effect can occur regardless of individual dispersal rates (i.e., environmental control sensu Heino et al., 2015b). Alternati-

Programa de Pós-Graduação em Ecologia de Ambientes Aquáticos Continentais, Universidade Estadual de Maringá, Av. Colombo, 5.790, Bloco G-90, 87020-900 Maringá, PR, Brazil. (AG) angelagutierrezc@gmail.com, Dhttps://orcid.org/0000-0002-4903-4231(corresponding author),(JCGO) ortegajean@gmail.com,(AAA) agostinhoaa@gmail.com 
vely, with increasing spatial scales, the dispersal capacity of species among communities will decrease; in contrast, the environmental heterogeneity increases (i.e., environmental control-dispersion; Heino et al., 2015b).

Temporal dynamics also influence beta diversity. In floodplains, the flood pulse is the main seasonal event that influences the abiotic and biotic structure (Junk et al., 1989). The increase in the river level connects isolated lakes in the floodplain to the main rivers and homogenizes the environmental variability (i.e., reduces environmental heterogeneity), while the receding of waters in the dry period increases the differences in the abiotic variables (i.e., increases environmental variability) from different lakes (Thomaz et al., 2007; Bozelli et al., 2015). Flood pulses can also homogenize the species composition, as the increase in river level connects isolated lakes and the main river channel, enabling the dispersal of species (Thomaz et al., 2007). Thus, floods can mix faunas and reduce beta diversity during flood periods; however, beta diversity can increase during periods of drought because isolation increases due to the absence of channels that connect ponds to the main rivers (Thomaz et al., 2007; Bozelli et al., 2015; Penha et al., 2017).

Organisms from different taxonomic groups may respond differently to the effects of environmental heterogeneity (Soininen et al., 2007; Padial et al., 2014; Heino, 2001; Heino et al., 2015b) and seasonal events (Padial et $a l ., 2014)$, which is why ecological studies consider the diversity of functional traits or the phylogeny of species; these studies can facilitate a better understanding of community dynamics (Swenson et al., 2011). A useful tool for this approach is the classification of species into guilds (e.g., trophic or reproductive guilds). A guild can be considered as a group of species that exploit a common resource or exhibit similar behaviors (e.g., reproductive traits; Kikkawa, Anderson, 1986). This approach can provide a detailed view of the processes that influence beta diversity (Padial et al., 2014; Brownscombe et al., 2017).

Neotropical floodplains are models for evaluating the effects of environmental heterogeneity and seasonality on the beta diversity of fish assemblages. These environments are subjected to seasonal droughts and floods (Junk et al., 1989; 2014; Thomaz et al., 2007), with the latter homogenizing the abiotic conditions and increasing the connectivity of isolated environments with the main river channels (Thomaz et al., 2007). Neotropical ichthyofauna has enormous species richness (Lévêque et al., 2008), and species have different ecological roles. In terms of reproductive aspects, these species can be grouped as migratory or sedentary species, and the latter may or may not exhibit parental care. It is expected that migratory species have greater dispersal potential (Padial et al., 2014), which is closely related to flood connectivity (Oliveira et al., 2015).

In terms of trophic aspects, fish exhibit great plasticity, but groups of detritivorous, herbivorous, insectivorous, omnivorous and piscivorous species can be recognized within a community (Abelha et al., 2001). This variety of trophic sta- tuses may influence the responses of fish to variations in local or regional environmental factors (Heino et al., 2015b). The variations in environmental conditions produced by flood pulses influence the availability of food for different guilds throughout the year. It is expected that this variation in the availability of resources affects the composition of the trophic guilds because it favors the wide distribution and presence of some species and negatively affects others, producing variations in the beta diversity linked to the different guilds. However, there are no previous studies that predict the behavior of insectivorous, herbivorous, detritivorous and omnivorous guilds; therefore, by considering ecological dynamics, distinct trends in beta diversity variation among guilds can be expected.

This study evaluates the effect of environmental heterogeneity and floods on the beta diversity of fishes in the upper Paraná River floodplain. The hypotheses evaluated were that there is a positive correlation between beta diversity and environmental heterogeneity, that beta diversity is smaller in flood periods than in dry periods and that these relations change from one guild to another. One can expect that these relations change with guilds because the exploration of food resources and the dispersal activities associated with each guild may influence their responses to environmental heterogeneity and seasonal events, which can scale to compositional differences (Soininen et al., 2007; Padial et al., 2014). For instance, during the dry period, piscivorous species will benefit from the increase in the availability of the species that serve as food because prey species are restricted to a smaller area than that during the flood period (Luz-Agostinho et al., 2008). On the other hand, variations in omnivore beta diversity are not expected because omnivores have greater food plasticity and can find food resources at all times throughout the hydrological cycle (Hahn et al., 2004). Similarly, in terms of reproductive guilds, migratory species travel longer distances than do species with some parental care traits (Suzuki et al., 2004); thus, the former may be more likely than the latter to present different species composition (i.e., higher beta diversity).

\section{Material and Methods}

Study area. Sampling was conducted in the floodplain of the upper Paraná River, in the stretch bounded between the upstream Porto Primavera Dam and the downstream Itaipu Reservoir, which is the only stretch of the Paraná River in the Brazilian territory that is free of impoundments. In this section, the river has an anastomosed channel that is characterized by a low slope $(0.09 \mathrm{~m} / \mathrm{km})$, a wide floodplain and a high sedimentation rate, which generates bars and islands (Souza-Filho, Stevaux, 1997). The main channels of the drainage network in the lowlands are the Paraná, Ivinhema and Baía rivers, which are interconnected by secondary channels. The lagoons have permanent or intermittent connections with these channels, depending on the water levels of the main rivers (Vazzoler et al., 1997) (Fig. 1). 


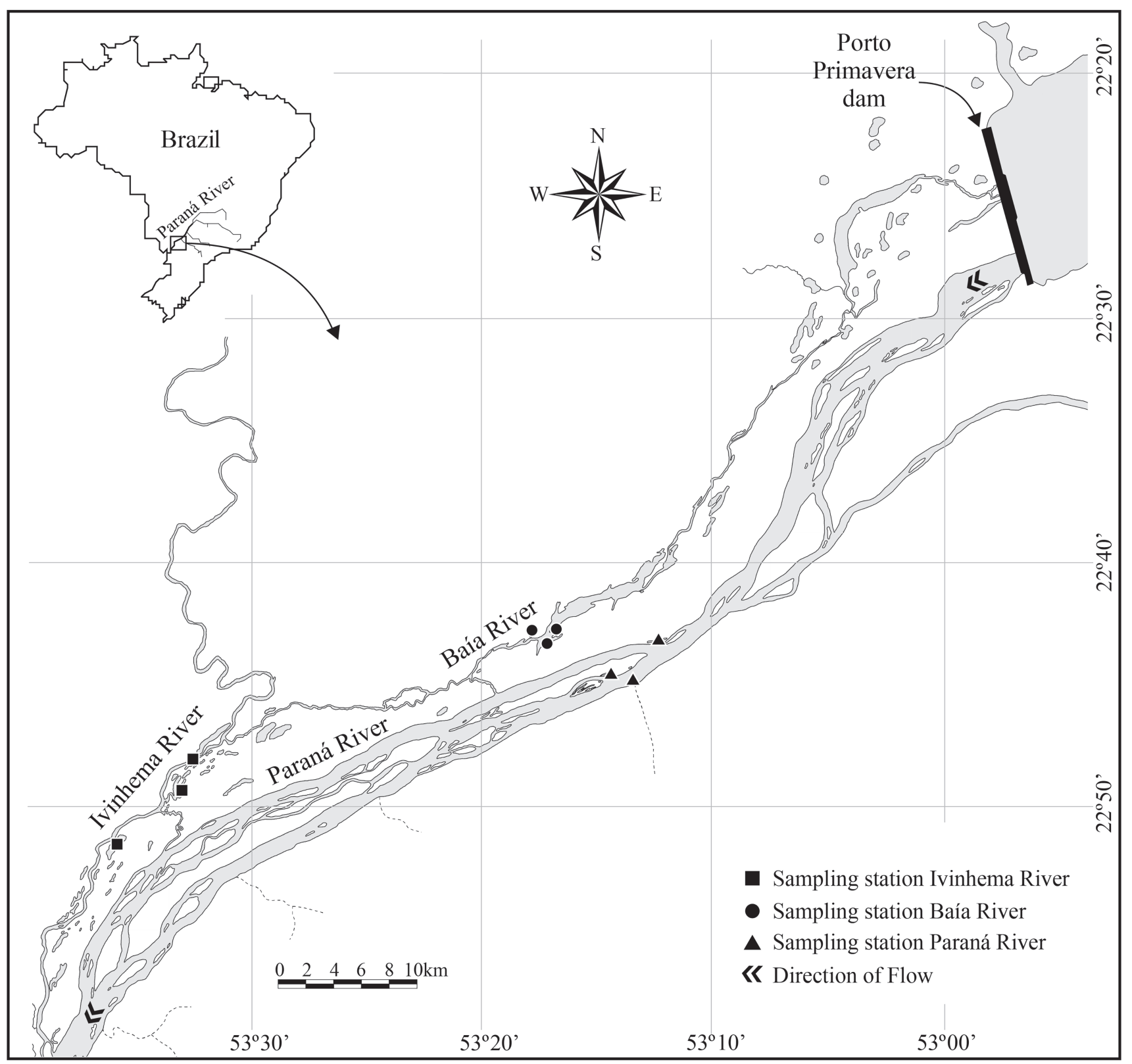

Fig. 1. Map of the Upper Paraná River floodplain. The triangles represent the sampling stations of the Paraná River sub-basin, the circles represent the sampling stations of the Baía River sub-basin, and the squares represent the sampling stations of the Ivinhema River sub-basin.

Sampling. Fish sampling was performed quarterly between 2000 and 2012 (i.e., a total of 50 sampling campaigns were conducted) at nine collection stations; specifically, two lakes and the main channel of the river in each sub-basin were considered. In the sub-basin of the Paraná River, both Pousada das Garças and Ressaco do Pau Velho lakes, which have permanent connectivity to the Paraná River, were sampled; in the Baía sub-basin, Guaraná Lake, which has a permanent connection, and Closed Lake, which is isolated during the dry season, were sampled; finally, in the sub-basin of the Ivinhema River, Patos Lake, which has a permanent connection, and Ventura Lake, which has a seasonal connection, were sampled (Fig. 1).
Gillnets of different mesh sizes were used (30, 40, 50, $60,70,80,100,120,140$, and $160 \mathrm{~mm}$ between opposed knots); nets were deployed for $24 \mathrm{~h}$, and fish were removed in the morning, afternoon and evening. The specimens were identified according to Ota et al. (2018), and voucher specimens were deposited in the Coleção Ictiológica of the Núcleo de Pesquisas em Limnologia, Ictiologia e Aquicultura (NUPELIA) of the Universidade Estadual de Maringá (UEM). Abundance data were indexed by catch per unit effort (CPUE) (individuals/24 $\mathrm{h} / 1000 \mathrm{~m}^{2}$ ).

Species were classified into six trophic guilds based on previous studies conducted in the region (Hahn et al., 
1997; 2004) and complementary information from the literature (Tab. S1 - Available only as online supplementary file accessed with the online version of the article at http://www.scielo.br/ni); these guilds included species that were detritivorous (DET), herbivorous (HER), insectivorous (INS), invertivorous (INV), omnivorous (ONI) and piscivorous (PIS). The four reproductive guilds followed the classification scheme proposed by Suzuki et al. (2004), i.e., long-distance migratory and external fertilization (LMEF), non-migratory with external fertilization and parental care (NEFC), non-migratory with external fertilization without parental care (NEFW) and non-migratory with internal fertilization (NIF) species. We then generated 10 matrices using the per species CPUE data from each guild.

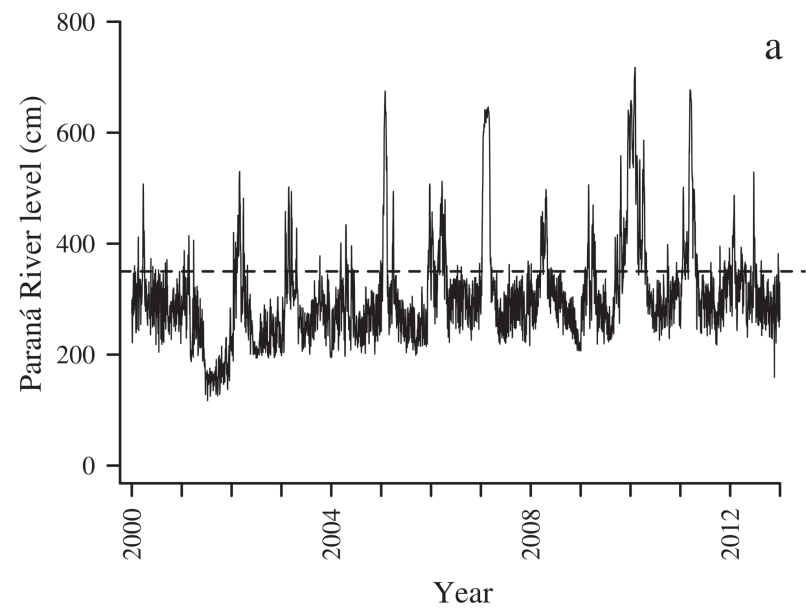

Fig. 2. Hydrometric-level (a) and environmental heterogeneity (b) variation between 2000 and 2012 in the Paraná River. The horizontal black dashed line indicates the flood level of the floodplain. Source: ANA - Estação Fluviométrica of Porto São José, PR.

Data analysis. Environmental heterogeneity was measured based on the mean dispersion among the samples in a multivariate space (Anderson et al., 2006; Al-Shami et al., 2013). The rationale for this approach was that sampling periods with a greater average distance to the centroid of the physicochemical variables presented greater environmental heterogeneity (Anderson et al., 2006; Al-Shami et al., 2013). First, the matrix of physicochemical variables was centralized by subtracting each observation of each variable from its mean and then dividing that value by its standard deviation. The centralized matrix was transformed into a Euclidean distance matrix and used to order the samples (sample sites per collection period per year) using principal coordinate analysis (PCoA). Then, the mean distance between each sample and the centroid of the group was calculated (Anderson et al., 2006; dry or flood season by year).

Beta diversity was measured using the same procedure as that used for environmental heterogeneity. The CPUE matrix of each guild was first transformed by $\log 10(\mathrm{x}+1)$ and then transformed into a Bray-Curtis dissimilarity matrix. The logarithmic transformation was applied on the raw CPUE matrix to downweigh rare and abundant species in
To measure EH, 15 physicochemical variables were measured: water temperature $\left({ }^{\circ} \mathrm{C}\right)$, transparency (Secchi depth; $\mathrm{cm}), \mathrm{pH}$, conductivity $(\mu \mathrm{S})$, dissolved oxygen $(\mathrm{mg} / \mathrm{L})$, alkalinity $(\mathrm{mEq} / \mathrm{L})$, inorganic suspended material $(\mathrm{mg} / \mathrm{L})$, suspended organic material $(\mathrm{mg} / \mathrm{L})$, chlorophyll-a $(\mathrm{mg} / \mathrm{L})$, total nitrogen concentration $(\mathrm{mg} / \mathrm{L})$, ammonia concentration $\left(\mathrm{NH}_{4} ; \mathrm{mg} / \mathrm{L}\right)$, total phosphorus concentration $(\mathrm{mg} / \mathrm{L})$, phosphate concentration $\left(\mathrm{PO}_{4} ; \mathrm{mg} / \mathrm{L}\right)$ and zooplankton abundance (individuals/ml) (Tab. S2 - Available only as online supplementary file accessed with the online version of the article at http://www.scielo.br/ni). For each sampling campaign, the average value of each variable was calculated. Additionally, the river-level data (m) were measured at the Estação Fluviométrica of Porto São José, which is operated by the Agência Nacional de Águas (Fig. 2).

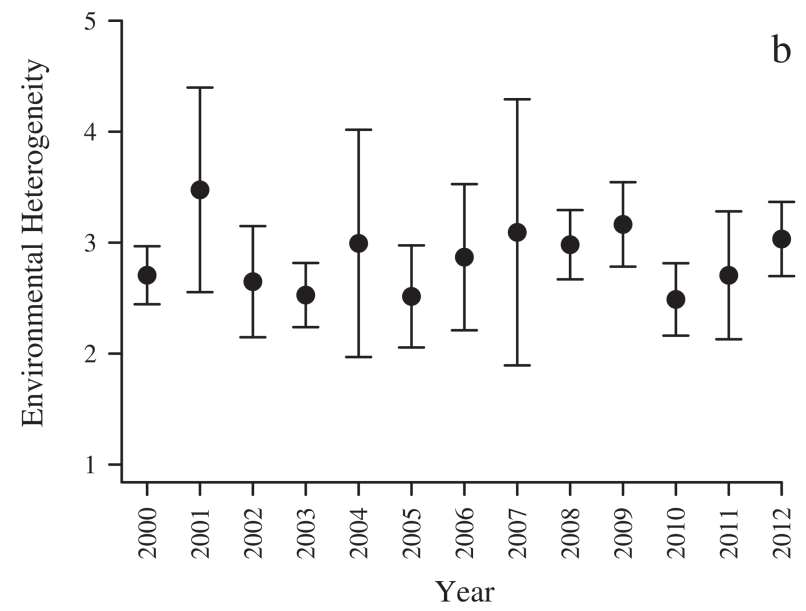

the ordination results. The Bray-Curtis dissimilarity matrix was used to order the samples using PCoA, and then the mean distance to the centroid of the groups (i.e., the sampling period) was calculated. This average distance to the centroid was the measure of beta diversity for each sampling period. Sampling periods with higher mean distances relative to the centroid of species composition showed greater beta diversity (Anderson et al., 2006). Beta diversity was calculated for a species composition matrix using each trophic or reproductive guild (Fig. 3).

The influence of the period (a categorical variable with two levels: dry and flood) and the mean distance to the environmental centroid (a continuous variable represented by environmental heterogeneity) on the beta diversity (i.e., the response variable) was evaluated using generalized least squares (GLS) linear models. When estimating the parameters of the linear model, GLS allows for the insertion of correlation structures in the residuals of the model, which results in more precise parameter estimates (Zuur et al., 2009). This approach was used to overcome the potential lack of independence among sampling units because sampling campaigns that were closer in time may present similar values of 
1

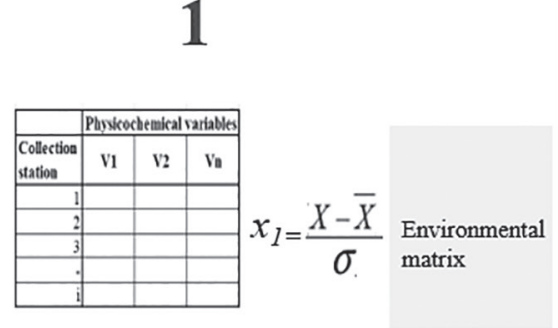

\section{Environmental data}

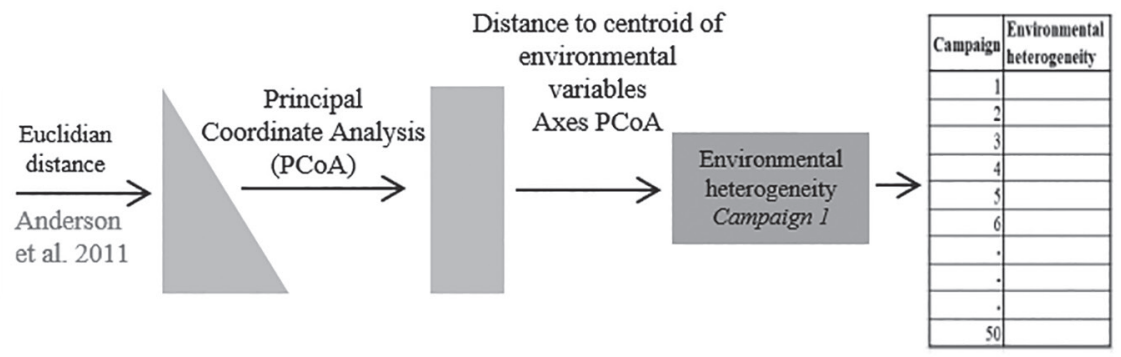

Standardized environmental

data

(Legendre \& Legendre 1998)

\section{$2 \quad$ Biological data}

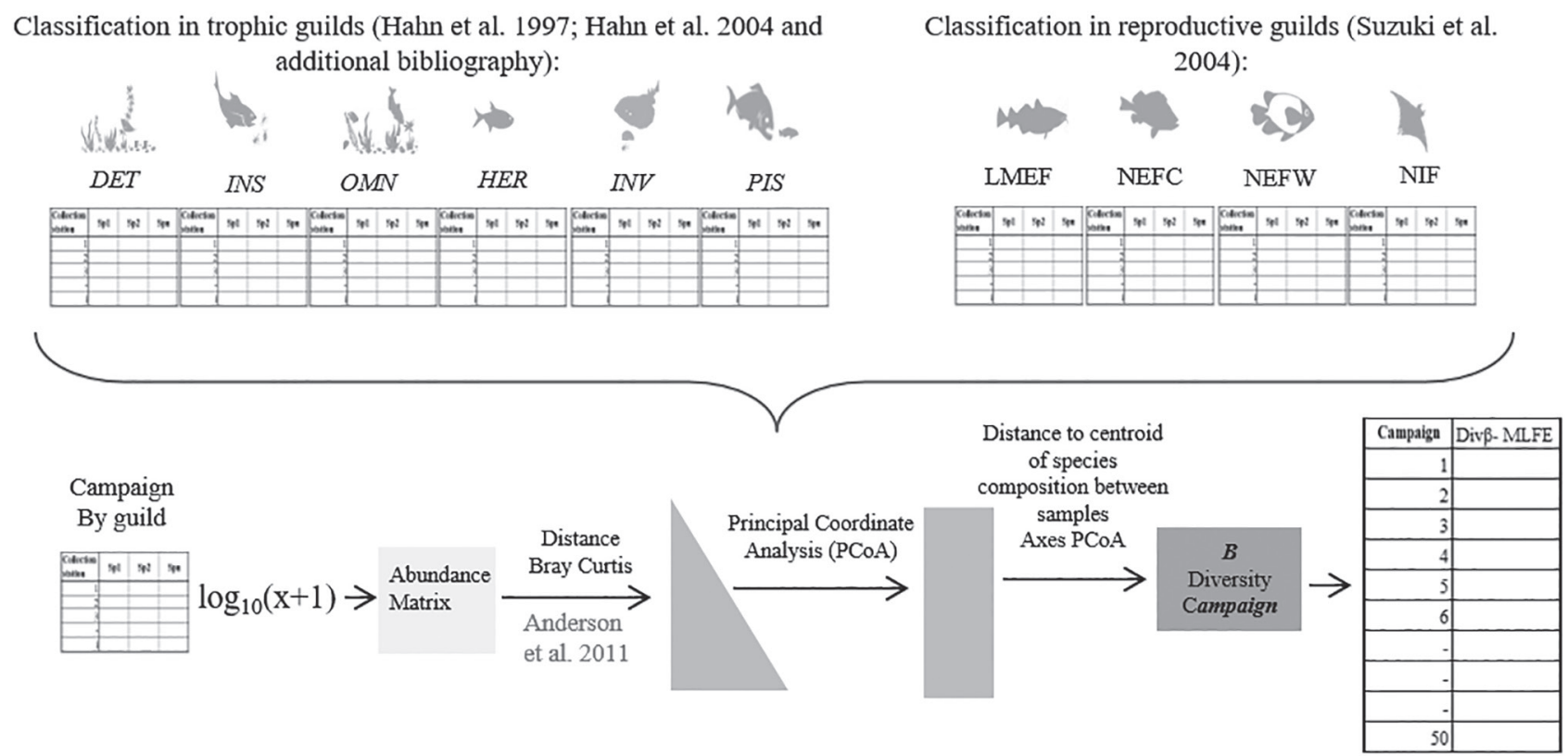

Fig. 3. Data analysis procedure for environmental heterogeneity and beta diversity for the different matrices of the trophic and reproductive guilds.

beta diversity or environmental heterogeneity (e.g., Zuur et al., 2009; Ceschin et al., 2018). Different structures of correlation (i.e., no structure, first-order autoregressive, exponential, Gaussian, linear, rational quadratic, spherical, correlation matrix without structure; Pinheiro, Bates, 2000) were evaluated using the Akaike information criterion (AIC), and inferences were made using the model with the smallest AIC value. If more than one model shared the lowest AIC value, either of the two models was arbitrarily interpreted since the parameter estimates, standard errors and significance tests were the same. The GLS models were constructed separately for each guild. The residuals of the GLS models were homogeneous, and there was no multicollinearity since the hydrological period and the environmental heterogeneity were not correlated (polyserial correlation (Drasgow, 1986; Fox, 2016): $\rho=-0.26, P=0.56)$.
A significance level of 5\% was adopted. All analyses were performed using the software R (R Core Team, 2015); additionally, the 'vegan' package (Oksanen et al., 2015) was used to compute the distance to the centroid with the "permdisp' function, and the 'nlme' package (Pinheiro et al., 2015) was used for the GLS parameter estimates.

\section{Results}

The mean beta diversity measured for the reproductive guilds varied from 0.94 (non-migratory with internal fertilization) to 2.37 (non-migratory with external fertilization without parental care) (Fig. 4). For trophic guilds, herbivorous species presented the lowest mean values of beta diversity, while piscivorous and omnivorous species presented the highest values of beta diversity (Fig. 4). 


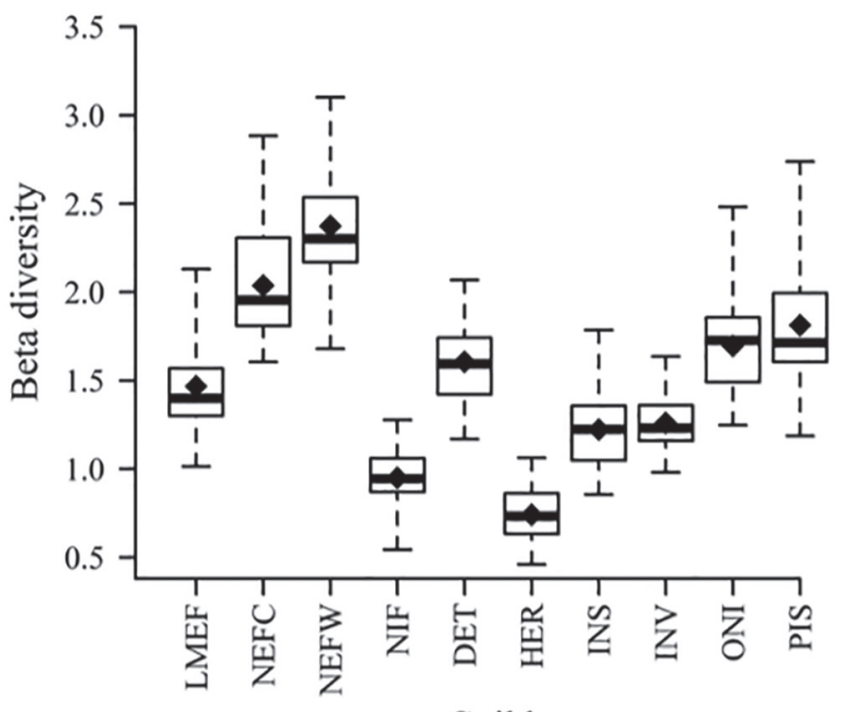

Guilds

Fig. 4. Beta diversity variation among the guilds. The boxes represent the interquartile ranges, the horizontal lines indicate the medians, the bars indicate the minimum and maximum values, and the closed diamonds represent the mean beta diversity of each guild. LMEF: long-distance migratory and external fertilization; NEFC: non-migratory with external fertilization and parental care; NEFW: nonmigratory with external fertilization without parental care; NIF: non-migratory with internal fertilization; DET: detritivorous; HER: herbivorous; INS: insectivorous; INV: invertivorous; ONI: omnivorous; and PIS: piscivorous.

The models indicated that the incorporation of autocorrelation structures improved the parameter estimates, except for the non-migratory with internal fertilization guild
(Tab. S3 - Available only as online supplementary file accessed with the online version of the article at http://www.scielo.br/ni). The first-order autocorrelation process described the correlation structure of the models for the species with long-distance migratory and external fertilization, non-migratory with external fertilization and parental care, non-migratory with external fertilization without parental care, and those that were detritivorous and piscivorous. The rational quadratic autocorrelation described the correlation structure of the model for the herbivorous, insectivorous, invertivorous and omnivorous trophic guilds.

In the non-migratory with external fertilization and parental care and the non-migratory with internal fertilization guilds (both guilds with parental care), the effect of environmental heterogeneity was moderated by the period (non-migratory with external fertilization and parental care: interaction between environmental heterogeneity and period, $t=$ $2.04, P=0.05$; non-migratory with internal fertilization: interaction between environmental heterogeneity and period, $t$ $=2.19, P=0.03$; Tab. 1; Fig. 5). For the non-migratory with external fertilization and parental care guild, during the dry period, the beta diversity tended to be higher as the environmental heterogeneity increased; in contrast, the beta diversity of this guild did not change in relation to the environmental heterogeneity during the flood period (Fig. 5a). The beta diversity of the non-migratory with internal fertilization guild followed a trend similar to that of the non-migratory with external fertilization and parental care guild during the dry period; however, during the flood period, there was a decreasing trend in beta diversity as environmental heterogeneity increased (Fig. 5b). The beta diversity of the other guilds did not vary in relation to periods or environmental heterogeneity (Tab. 1).
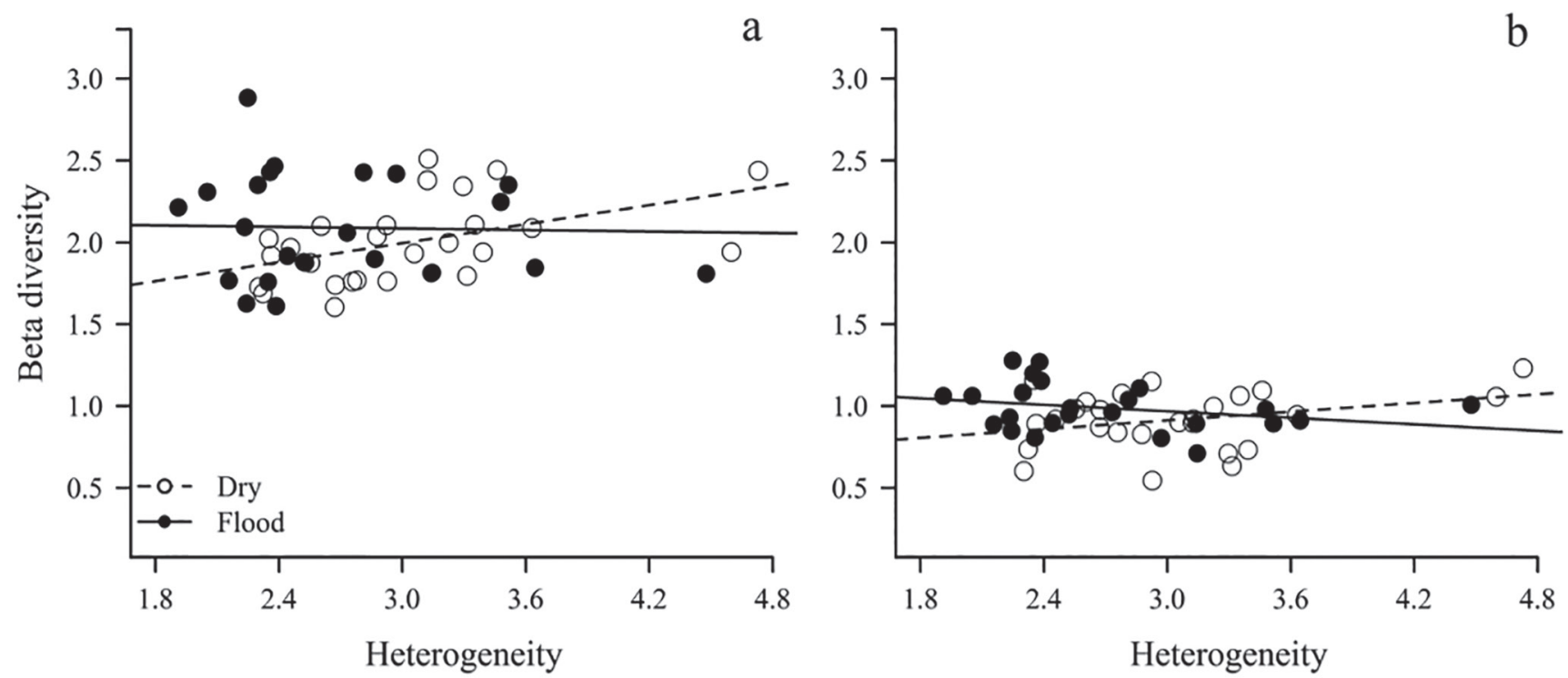

Fig. 5. Relationship between beta diversity (mean distance to centroid), environmental heterogeneity and period of the hydrological cycle. a. Beta diversity of non-migratory fish species with external fertilization and parental care (NEFC); b. beta diversity of non-migratory fish species with internal fertilization (NIF). 
Tab. 1. Parameter estimates of generalized least squares linear models relating the beta diversity of each guild to the period and the environmental heterogeneity (EH). SE: standard error of the estimate. LMEF: long-distance migratory and external fertilization; NEFC: non-migratory with external fertilization and parental care; NEFW: nonmigratory with external fertilization without parental care; NIF: non-migratory with internal fertilization; DET: detritivorous; HER: herbivorous; INS: insectivorous; INV: invertivorous; ONI: omnivorous; and PIS: piscivorous. EH*Per: interaction term between $\mathrm{EH}$ and period. The degrees of freedom for each parameter were 1 , and the residual degrees of freedom of each model were $46 .{ }^{*}$ The estimated parameters for the rational quadratic and $1^{\text {st }}$ order autocorrelation were range and phi, respectively.

\begin{tabular}{|c|c|c|c|c|c|}
\hline Guild & Parameter & Estimate & $\mathrm{SE}$ & $t$ & $P$ \\
\hline \multirow[t]{5}{*}{ MLFE } & Intercept & 1.66 & 0.18 & 9.26 & $<0.01$ \\
\hline & Period & -0.11 & 0.24 & -0.47 & 0.64 \\
\hline & EH & -0.10 & 0.06 & -1.73 & 0.09 \\
\hline & EH*Per & 0.09 & 0.08 & 1.13 & 0.26 \\
\hline & $1^{\text {st }}$ order autocorrelation & 0.64 & & & \\
\hline \multirow[t]{5}{*}{ NFEC } & Intercept & 2.14 & 0.21 & 10.10 & $<0.01$ \\
\hline & Period & -0.72 & 0.31 & -2.37 & 0.02 \\
\hline & EH & -0.02 & 0.07 & -0.24 & 0.81 \\
\hline & EH*Per & 0.20 & 0.10 & 2.04 & 0.05 \\
\hline & $1^{\text {st }}$ order autocorrelation & 0.52 & & & \\
\hline \multirow[t]{5}{*}{ NFES } & Intercept & 2.52 & 0.21 & 11.79 & $<0.01$ \\
\hline & Period & -0.52 & 0.30 & -1.74 & 0.09 \\
\hline & $\mathrm{EH}$ & -0.05 & 0.07 & -0.67 & 0.51 \\
\hline & $\mathrm{EH}^{*}$ Per & 0.16 & 0.10 & 1.66 & 0.10 \\
\hline & $1^{\text {st }}$ order autocorrelation & 0.61 & & & \\
\hline \multirow[t]{4}{*}{ NFI } & Intercept & 1.11 & 0.15 & 7.62 & $<0.01$ \\
\hline & Period & -0.54 & 0.21 & -2.53 & 0.01 \\
\hline & EH & -0.05 & 0.05 & -0.88 & 0.38 \\
\hline & EH*Per & 0.15 & 0.07 & 2.19 & 0.03 \\
\hline \multirow[t]{5}{*}{ DET } & Intercept & 1.31 & 0.18 & 7.3 & $<0.01$ \\
\hline & Period & -0.04 & 0.26 & -0.13 & 0.89 \\
\hline & EH & 0.09 & 0.06 & 1.58 & 0.12 \\
\hline & EH*Per & 0.03 & 0.08 & 0.32 & 0.75 \\
\hline & $1^{\text {st }}$ order autocorrelation & 0.48 & & & \\
\hline \multirow[t]{5}{*}{ HER } & Intercept & 0.69 & 0.13 & 5.47 & $<0.01$ \\
\hline & Period & -0.16 & 0.18 & -0.89 & 0.37 \\
\hline & EH & 0.01 & 0.04 & 0.11 & 0.91 \\
\hline & EH*Per & 0.08 & 0.06 & 1.35 & 0.18 \\
\hline & Rational quadratic autocorrelation & 0.55 & & & \\
\hline \multirow[t]{5}{*}{ INS } & Intercept & 1.24 & 0.17 & 7.36 & $<0.01$ \\
\hline & Period & -0.14 & 0.25 & -0.55 & 0.59 \\
\hline & $\mathrm{EH}$ & -0.03 & 0.06 & -0.44 & 0.66 \\
\hline & EH*Per & 0.08 & 0.08 & 0.99 & 0.33 \\
\hline & Rational quadratic autocorrelation & 0.73 & & & \\
\hline \multirow[t]{3}{*}{ INV } & Intercept & 1.20 & 0.12 & 10.14 & $<0.01$ \\
\hline & Period & 0.11 & 0.17 & 0.64 & 0.52 \\
\hline & EH & 0.02 & 0.04 & 0.44 & 0.66 \\
\hline
\end{tabular}

\begin{tabular}{llcccc}
\hline Guild & Parameter & Estimate & $\mathrm{SE}$ & $t$ & $P$ \\
\hline \multirow{4}{*}{ ONI } & EH*Per & -0.03 & 0.06 & -0.48 & 0.63 \\
& Rational quadratic autocorrelation & 0.61 & & & \\
& Intercept & 1.85 & 0.23 & 8.21 & $<0.01$ \\
& Period & -0.65 & 0.33 & -1.94 & 0.06 \\
& EH & -0.03 & 0.08 & -0.45 & 0.65 \\
& EH*Per & 0.18 & 0.11 & 1.64 & 0.11 \\
& Rational quadratic autocorrelation & 0.59 & & & \\
Intercept & 1.97 & 0.23 & 8.55 & $<0.01$ \\
& Period & -0.60 & 0.33 & -1.81 & 0.08 \\
& EH & -0.04 & 0.07 & -0.47 & 0.64 \\
& EH*Per & 0.16 & 0.11 & 1.55 & 0.13 \\
& $1^{\text {st }}$ order autocorrelation & 0.53 & & & \\
\hline
\end{tabular}

\section{Discussion}

Several authors have reported positive relationships between beta diversity and environmental heterogeneity for many groups of organisms with different dispersion abilities (Soininen et al., 2007; Bini et al., 2014; Heino et al., 2015b); this result is expected because heterogeneous conditions increase niche opportunities for a greater number of different species than do homogeneous conditions (Bini et al., 2014). Thus, the increase in environmental heterogeneity reduces the similarity in assemblage composition and, consequently, increases beta diversity. The observed results suggest that this relationship may be particularly important for sedentary guilds because they cannot disperse to sites with better environmental conditions; thus, these guilds experience competition processes that can generate local extinctions that increase beta diversity. For instance, if two sites share the same species composition, the local extinction of a species from one site will increase the difference in composition (i.e., an increase in beta diversity) between both sites (O1den, Poff, 2003; Petsch, 2016).

The hypothesis proposed in this study was partially supported since only the beta diversity of two guilds varied as a function of environmental heterogeneity or differed between periods of the hydrological cycle. None of the trophic guilds had beta diversity values that responded to the influence of environmental heterogeneity and periods of the hydrological cycle; these results suggest that (i) the beta diversity of trophic guilds is poorly predicted by these variables, and (ii) fish feeding is plastic enough to adapt to environmental changes without changing the composition of the fish assemblages that were analyzed in the Upper Paraná River floodplain. The effect of environmental heterogeneity on beta diversity was mediated by floods and dry periods in only two reproductive guilds, both of which had parental care (i.e., non-migratory with external fertilization and parental care and non-migratory with internal fertilization). In these guilds, during the dry period, a positive relationship was observed between environmental heterogeneity and beta diversity. This result can be explained by the fact that species with parental care may have a lower dispersion ca- 
pacity. This lower dispersion capacity causes a shorter duration of movements (Giam, Olden, 2018) because species that demonstrate parental care invest time and energy in caring for offspring instead of other activities, such as somatic growth, feeding and gonadal development (McBride et al., 2015; Brownscombe et al., 2017). When environmental conditions are not optimal, species of guilds with parental care may have more difficulty in dispersing to more suitable environments, and this lack of dispersion between environments increases the dissimilarity in the composition of the assemblages of these guilds (Heino, Grönroos, 2013).

The beta diversity of guilds that do not show parental care did not show variation in relation to environmental heterogeneity or dry and flood periods. A possible explanation for this lack of relationship is the active dispersal of these fish (Suzuki et al., 2004). Fish dispersal is limited to the existence of channels connecting waterbodies (Suzuki et al., 2004; Padial et al., 2014; Penha et al., 2017). Thus, even an ephemeral connection between lakes and the main river in the dry period may allow fish dispersal and their presence in different sites, which may hinder a potential effect caused by the hydrological period. This hypothesis may even apply to guilds that do not migrate long distances. It is also worth mentioning that intermittent flow pulses that occur on the floodplain as a result of the operation of upstream dams to meet daily or weekly peaks in energy demand may have a potential influence (Souza-Filho et al., 2004). These oscillations can provide sufficient connections that homogenize assemblages even in periods of drought. In addition, beta diversity may possibly be influenced by variables that were not considered in this work, such as primary productivity (Bini et al., 2014) and interspecific interactions (Van Allen et al., 2017).

Recently, several authors have questioned the relationship between beta diversity and environmental heterogeneity. Chase (2010) observed a weak or even absent relationship between environmental heterogeneity and beta diversity in experimental ponds, indicating that other factors, such as productivity, can control variation in beta diversity. Apparently, in environments with higher temperatures and nutrient richness, stochastic processes can determine the variation in beta diversity (Chase, 2010). In addition, Al-Shami et al. (2013) reported that environmental heterogeneity was not necessarily associated with beta diversity; rather, environmental heterogeneity may be collinear with other environmental variables that influence beta diversity. Heino et al. (2015a) reasoned that several factors influenced the environmental heterogeneity and beta diversity relationship, including the size of the study area, regional history, landscape characteristics and differential dispersal abilities of organisms. These studies show that even as our understanding about beta diversity patterns improves, we are still far from having a concise interpretation, especially in tropical floodplain ecosystems.

In conclusion, the compositions of the non-migratory with external fertilization and parental care and the non-migratory with internal fertilization guilds were more sensitive to environmental heterogeneity, which was caused by the pulse of droughts and floods. On the other hand, the lack of interaction between the beta diversity and the environmental heterogeneity generated by the hydrological cycle in the other guilds may indicate that, in fish assemblages with high dispersion rates, the variation in beta diversity has no clear pattern, and it may be necessary to reconsider the processes that are currently used to interpret the relationship between beta-diversity, environmental heterogeneity and flood pulses. Specifically, the predicted positive relationship between beta-diversity and environmental heterogeneity or isolation (dry periods in our case) may not hold for guilds with high dispersal potential of these guilds (Logue et al., 2011; Heino et al., 2015a). The results of this study further suggest that reproductive guilds influence the assessment of correlates effects on beta diversity variation, such as environmental heterogeneity and flood events. Assessing the variation of beta-diversity separately by guilds other than dispersal in a deconstruction framework (sensu Marquet et al., 2004) may provide information that dispersal alone cannot provide and to help to disentangle dispersal and environmental filtering effects on beta diversity. For instance, non-migratory guilds may be more prone to dispersal limitation. However, only the beta-diversity of guilds with some type of parental care responded to environmental heterogeneity and floods, suggesting that these guilds were more likely to be influenced by environmental filtering than non-migrants without parental care.

\section{Acknowledgments}

We thank the Núcleo de Pesquisas em Limnologia, Ictiologia e Aquicultura (Nupélia) and the Programa de Pesquisas Ecológicas de Longa Duração (PELD/CNPq) that provided the infrastructure and database access required for this research. We are grateful to the constructive comments of anonymous reviewers that improved the manuscript. AG and JCGO thank the CNPq for scholarships, and AAA received $\mathrm{CNPq}$ research grants.

\section{References}

Abelha MCF, Agostinho AA, Goulart E. Plasticidade trófica em peixes de água doce. Acta Sci. 2001; 23(2):425-34.

Al-Shami SA, Heino J, Che Salmah MR, Hassan AA, Suhaila AH, Madrus MR. Drivers of beta diversity of macroinvertebrate communities in tropical forest streams. Freshw Biol [serial on the Internet]. 2013; 58(6):1126-37. Available from: https://doi. org/10.1111/fwb.12113

Anderson MJ, Crist TO, Chase JM, Vellend M, Inouye BD, Freestone AL et al. Navigating the multiple meanings of $\beta$ diversity: a roadmap for the practicing ecologist. Ecol Lett [serial on the Internet]. 2011; 14(1):19-28. Available from: https://doi.org/10.1111/j.1461-0248.2010.01552.x

Anderson MJ, Ellingsen KE, McArdle BH. Multivariate dispersion as a measure of beta diversity. Ecol Lett [serial on the Internet]. 2006; 9(6):683-93. Available from: https://doi.org/10.1111/ j.1461-0248.2006.00926.x 
Bini LM, Landeiro VL, Padial AA, Siqueira T, Heino J. Nutrient enrichment is related to two facets of beta diversity for stream invertebrates across the United States. Ecology [serial on the Internet]. 2014; 95(6):1569-78. Available from: https://doi. org/10.1890/13-0656.1

Bozelli RL, Thomaz SM, Padial AA, Lopes PM, Bini LM. Floods decrease zooplankton beta diversity and environmental heterogeneity in an Amazonian floodplain system. Hydrobiologia [serial on the Internet]. 2015; 753(1):233-41. Available from: https://doi.org/10.1007/s10750-015-2209-1

Brownscombe JW, Cooke SJ, Algera DA, Hanson KC, Eliason EJ, Burnett NJ et al. Ecology of exercise in wild fish: Integrating concepts of individual physiological capacity, behavior, and fitness through diverse case. Integr Comp Biol [serial on the Internet]. 2017; 57(2):281-92. Available from: https://doi. org/10.1093/icb/icx012

Ceschin F, Bini LM, Padial AA. Correlates of fish and aquatic macrophyte beta diversity in the Upper Paraná River floodplain. Hydrobiologia [serial on the Internet]. 2018; 805(1):377-89. Available from: https://doi.org/10.1007/s10750-017-3325-x

Chase JM. Stochastic community assembly causes higher biodiversity in more productive environments. Science [serial on the Internet]. 2010; 328(5984):1388-91. Available from: https://doi.org/10.1126/science. 1187820

Drasgow F. Polychoric and polyserial correlations. In: Kotz S, Johnson N, editors. The Encyclopedia of Statistics. New Jersey: John Wiley \& Sons; 1986. p.68-74.

Fox J. polycor: Polychoric and polyserial correlations [computer software manual - Internet]. R package version 0.7-9; 2016. Available from: https://CRAN.R-project.org/package=polycor

Giam X, Olden JD. Drivers and interrelationships among multiple dimensions of rarity for freshwater fishes. Ecography [serial on the Internet]. 2018; 41(2):331-44. Available from: https://doi. org/10.1111/ecog.02946

Hahn NS, Agostinho AA, Goitein R. Feeding ecology of curvina Plagioscion squamosissimus (Heckel, 1840) (Osteichthyes, Perciformes) in the Itaipu Reservoir and Porto Rico floodplain. Acta Limnol Bras. 1997; 9:11-22.

Hahn NS, Fugi R, Andrian IF. Trophic ecology of the fish assemblages. In: Thomaz SM, Agostinho AA, Hahn NS, editors. The Upper Paraná River and its floodplain: physical aspects, ecology and conservation. Leiden: Backhuys Publishers; 2004. p.247-269.

Heino J. Regional gradient analysis of freshwater biota: do similar biogeographic patterns exist among multiple taxonomic groups? J Biogeogr [serial on the Internet]. 2001; 28(1):69-76. Available from: https://doi.org/10.1046/j.1365-2699.2001.00538.x

Heino J, Grönroos M. Does environmental heterogeneity affect species co-ocurrence in ecological guilds across stream macroinvertebrate metacommunity. Ecography [serial on the Internet]. 2013; 36(8):926-36. Available from: https://doi. org/10.1111/j.1600-0587.2012.00057.x

Heino J, Melo AS, Bini LM. Reconceptualising the beta diversityenvironmental heterogeneity relationship in running water systems. Freshw Biol [serial on the Internet]. 2015a; 60(2):22335. Available from: https://doi.org/10.1111/fwb.12502
Heino J, Melo AS, Siqueira T, Soininen J, Valanko S, Bini LM. Metacommunity organisation, spatial extent and dispersal in aquatic systems: patterns process and prospects. Freshw Biol [serial on the Internet]. 2015b; 60(5):845-69. Available from: https://doi.org/10.1111/fwb.12533

Junk WJ, Bayley PB, Sparks RE. The flood-pulse concept in riverfloodplain systems. In: Dodge DP, editor. Proceedings of the International Large River Symposium (LARS), Canadian Journal of Fisheries and Aquatic Sciences Special Publication 106. Ottawa: NRC research press; 1989. p.110-127.

Junk WJ, Piedade MTF, Lourival R, Wittman F, Kandus P, Lacerda LD et al. Brazilian wetlands: their definition, delineation, and classification for research, sustainable management, and protection. Aquat Conserv [serial on the Internet]. 2014; 24(1):5-22. Available from: https://doi.org/10.1002/aqc. 2386

Kikkawa D, Anderson J. Community ecology: pattern and process. Honoken: Blackwell Publishing; 1986.

Leprieur F, Olden JD, Lek S, Brosse S. Contrasting patterns and mechanisms of spatial turnover for native and exotic freshwater fi $\mathrm{S}$ in Europe. J Biogeogr [serial on the Internet]. 2009; 36(10):1899-1912. Available from: https://doi.org/10.1111/ j.1365-2699.2009.02107.x

Lévêque C, Oberdorff T, Paugy D, Stiassny MLJ, Tedesco PA. Global diversity of fish (Pisces) in freshwater. In: Balian EV, Lévêque C, Segers H, Martens K, editors. Freshwater animal diversity assessment. Developments in Hydrobiologia. Dordrecht: Springer; 2008. p.545-567.

Logue JB, Mouquet N, Peter H, Hillebrand H, Metacommunity Working Group. Empirical approaches to metacommunities: a review and comparison with theory. Trends Ecol Evol [serial on the Internet]. 2011; 26(9):482-91. Available from: https:// doi.org/10.1016/j.tree.2011.04.009

Luz-Agostinho KDG, Agostinho AA, Gomes LC, Júlio-Jr HF. Influence of flood pulses on diet composition and trophic relationships among piscivorous fish in the Upper Paraná River floodplain. Hydrobiologia [serial on the Internet]. 2008; 607:187-98. Available from: https://doi.org/10.1007/s10750008-9390-4

Marquet PA, Fernández M, Navarrete SA, Valdovinos C. Diversity emerging: toward a deconstruction of biodiversity patterns. In: Lomolino M, Healey L, editors. Frontiers of biogeography: new directions in the geography of nature. Sunderland: Sinauer Associates; 2004. p.191-209.

McBride RS, Somarakis S, Fitzhugh GR, Albert A, Yaragina NA, Wuenschel MJ et al. Energy acquisition and allocation to egg production in relation to fish reproductive strategies. Fish Fish [serial on the Internet]. 2015; 16(1):23-57. Available from: https://doi.org/10.1111/faf.12043

Nekola JC, McGill BJ. Scale dependency in the functional form of the distance decay relationship. Ecography [serial on the Internet]. 2014; 37(4):309-20. Available from: https://doi. org/10.1111/j.1600-0587.2013.00407.x

Oksanen J, Blanchet FG, Kindt R, Legendre P, Minchin PR, O'Hara $\mathrm{RB}$ et al. vegan: Community ecology package [Computer software manual - Internet]. R package version 2.3-0; 2015. Available from: http://CRAN.R-project.org/package=vegan 
Olden JD, Poff NL. Toward a mechanistic understanding and prediction of biotic homogenization. Am Nat [serial on the Internet]. 2003; 162(4):442-60. Available from: https://doi. org/10.1086/378212

Oliveira AG, Suzuki HI, Gomes LC, Agostinho AA. Interspecific variation in migratory fish recruitment in the Upper Paraná River: effects of the duration and timing of floods. Environ Biol Fish [serial on the Internet]. 2015; 98(5):1327-37. Available from: https://doi.org/10.1007/s10641-014-0361-5

Ota RR, Deprá GC, Graça WJ, Pavanelli CS. Peixes da planície de inundação do alto rio Paraná e áreas adjacentes: revised, annotated and updated. Neotrop Ichthyol [serial on the Internet]. 2018; 16(2):e170094. Available from: https://doi. org/10.1590/1982-0224-20170094

Padial AA, Ceschin F, Declerck SAJ, De Meester L, Bonecker CC, Lansac-Tôha $\mathrm{F}$ et al. Dispersal ability determines the role of environmental, spatial and temporal drivers of metacommunity structure. PLoS One [serial on the Internet]. 2014; 9(10):e111227. Available from: https://doi.org/10.1371/ journal.pone.0111227

Penha J, Landeiro VL, Ortega JCG, Mateus L. Interchange between flooding and drying, and spatial connectivity control the fish metacommunity structure in lakes of the Pantanal wetland. Hydrobiologia [serial on the Internet]. 2017; 797(1):115-26. Available from: https://doi.org/10.1007/s10750-017-3164-9

Petsch DK. Causes and consequences of biotic homogenization in freshwater ecosystems. Int Rev Hydrobiol [serial on the Internet]. 2016; 101(3-4):113-22. Available from: https://doi. org/10.1002/iroh.201601850

Pinheiro JC, Bates DM. Mixed-effects models in S and S-PLUS. New York: Springer; 2000.

Pinheiro J, Bates D, DebRoy S, Sarkar D, R Core Team. nlme: Linear and nonlinear mixed effects models [Computer software manual - Internet]. R package version 3.1-120; 2015. Available from: http://CRAN.R-project.org/package=nlme

$\mathrm{R}$ Core Team. R: A language and environment for statistical computing [Computer software manual - Internet]. Vienna: R Foundation for Statistical Computing; 2015. Available from: http://www.R-project.org/

Soininen J, Lennon JJ, Hillebrand H. A multivariate analysis of beta diversity across organisms and environments. Ecology [serial on the Internet]. 2007; 88(11):2830-38. Available from: https://doi.org/10.1890/06-1730.1

Souza-Filho EE, Rocha PC, Comunello E, Stevaux JC. Effects of the Porto Primavera Dam on physical environment of the downstream floodplain. In: Thomaz SM, Agostinho AA, Hahn NS, editors. The Upper Paraná River and its floodplain: physical aspects, ecology and conservation. Leiden: Backhuys Publishers; 2004. p.55-74.

Souza-Filho EE, Stevaux JC. Geologia e geomorfologia do complexo rio Baía, Curutuba, Ivinhema. In: Vazzoler AE, Agostinho AA, Hahn NS, editors. A planície de inundação do rio Paraná: Aspectos físicos, biológicos e socioeconômicos. Maringá: Eduem; 1997. p.3-46.

Suzuki HI, Pelicice FM, Luiz EA, Latini JD, Agostinho AA. Reproductive strategies of the fish community of the Upper Paraná river floodplain. In: Agostinho AA, Rodrigues L, Gomes LC, Thomaz SM, Miranda LE, editors. Structure and functioning of the Paraná River and its floodplain. Maringá: Eduem; 2004. p.125-130.

Swenson N, Anglada-Cordero P, Barone JA. Deterministic tropical tree community turnover: evidence from patterns of functional beta diversity along an elevational gradient. Proc R Soc Lond B Biol Sci [serial on the Internet]. 2011; 278(1707):877-84. Available from: https://doi.org/10.1098/rspb.2010.1369

Thomaz SM, Bini LM, Bozelli RL. Floods increase similarity among aquatic habitats in river-floodplain systems. Hydrobiologia [serial on the Internet]. 2007; 579(1):1-13. Available from: https://doi.org/10.1007/s10750-006-0285-y

Van Allen BG, Rasmussen NL, Dibble CJ, Clay PA, Rudolf VHW. Top predators determine how biodiversity is partitioned across time and space. Ecol Lett [serial on the Internet]. 2017; 20(8):1004-13. Available from: https://doi.org/10.1111/ ele. 12798

Vazzoler AEAM, Agostinho AA, Hahn NS. A planície de inundação do Alto Rio Paraná: aspectos físicos, biológicos e sócio-econômicos. Maringá: Eduem; 1997.

Zorzal-Almeida S, Bini LM, Bicudo DC. Beta diversity of diatoms is driven by environmental heterogeneity, spatial extent and productivity. Hydrobiologia [serial on the Internet]. 2017; 800(1):7-16. Available from: https://doi.org/10.1007/s10750$017-3117-3$

Zuur A, Walker N, Saveliev AA, Smith GM. Mixed effects models and extensions in ecology with R. Berlin: Springer; 2009.

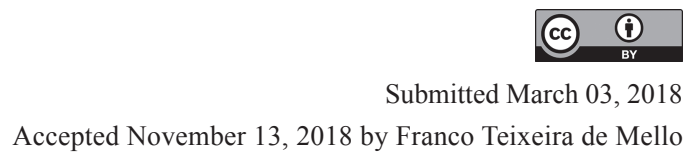

Submitted March 03, 2018 Accepted November 13, 2018 by Franco Teixeira de Mello 